\title{
APPLICATION OF VALUE STREAM MAPPING TOOL TO REDUCE WASTES IN BEARING INDUSTRY
}

\author{
Praveen Saraswat ${ }^{1}$, Deepak Kumar ${ }^{2}$ \\ ${ }^{1}$ M.Tech. Scholar, ${ }^{2}$ Associate Professor \\ ${ }^{1,2}$ Poornima College of Engineering, Jaipur
}

\begin{abstract}
In today's highly competitive business environment, companies require improvement in Production Lead Times, costs and customer service levels to survive. Because of this, companies have become more customers focused. The result is that companies have been putting in significant effort to improve their efficiency.
\end{abstract}

This paper present the practical application of Value Stream Mapping (VSM) tool implement in a bearing industry. A value stream is an assortment of all actions (value added as well as non-value added) that are required to bring a product through the essential flows, starting with raw material and ending with the customer. For drawing current state value stream mapping, all relevant data has been collected and analyzed. Then analysis of current state map has been done for identifying non-value adding activities, in other words waste and suggestions on how to remove or reduce different wastes. From the results achieved by current VSM, it was observable that the two processes Annealing and CNC Machining have higher cycle time and WIP. In order to increase their capacity, their cycle should be reduced.

By implementing some lean principles and changes in the production line, the future state map was created and the reduction the different types of wastes reduced. The total processing time was reduced from 409 seconds to 344 seconds.

\section{INTRODUCTION}

Lean manufacturing has increasingly been applied by leading manufacturing companies throughout the world. A core concept of lean manufacturing is pull production in which the flow on the factory floor is driven by demand from downstream pulling production upstream. Some of the changes required by lean manufacturing can be disruptive if not implemented correctly and some aspects of it are not appropriate for all companies. Value Stream Mapping (VSM) is used to define and analyze the current state for a product value stream and design a future state focused on reducing waste, improving lead-time, and improving workflow. One of the unique characteristics of VSM in comparison with other process analysis techniques is that one map depicts both material and information flow that controls the material flow. The focus of VSM is on a product "value stream" (all actions required to transform raw materials into a finished product) for a given "product family" -- products that follow the same overall production steps.

DOI : $10.14810 /$ ijmech.2014.3409 
Some advantages of Value Stream mapping are-

- It helps to see the sources of waste in the value stream

- It provides a common language for talking about the manufacturing process

- It makes the decision about flow apparent

- It ties together lean concepts and techniques, which helps avoid cherry picking

- It forms the basis of an implementation plan by designing the whole door-to-door flow

\section{RESEARCH METHODOLOGY}

Value Stream Mapping (VSM) is a pencil-and-paper tool that helps users see and understand the flow of material and information as products make their way through the value stream. The value stream includes the value-adding and non value-adding activities that are required to bring a product from raw material through delivery to the customer. In other words, VSM is an outline of a products manufacturing life cycle that identifies each step throughout the production process.

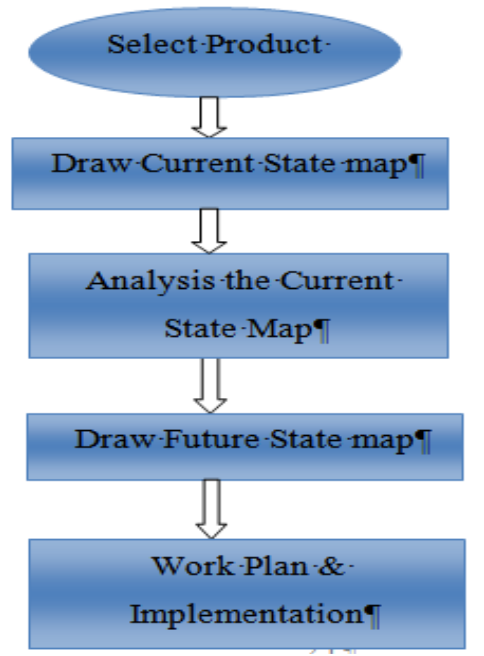

Figure- 1 Implement steps in value stream mapping

In order to draw value stream map following strategies applied:

- Obtained information from company

- Conducted time studies

- Data collected from shop flor observation.

- Edraw software is used to draw current and future state VSMs.

\section{CURRENT STATE VALUE STREAM MAP}

Before starting the data collection work first the final product must be sorted into the product families according to the problem. The first step in value stream mapping is to focus on one product family. In this research work UC- 208 inner (Used in plumber block) product is used for analysis. The different processes used in this product are as follows

- Bar Cutting

- Upsetting

- Piercing

- Annealing 
- CNC Machining

- Drilling

- Threading

- Inspection \& Packaging

The following data was observed in the current state map

Table 1 Value Stream Map Input Data

\begin{tabular}{|c|c|}
\hline Customer Order & 5000 (one week) \\
\hline Working Hours & One shift with 12 hours per day \\
\hline Break & One hour \\
\hline Raw Material & Weekly \\
\hline Working Day/ Month & 26 days \\
\hline
\end{tabular}

Table 2 Cycle Time and WIP of Different Processes

\begin{tabular}{|c|c|c|}
\hline Processes & $\begin{array}{c}\text { Avg. Cycle } \\
\text { Time }(\mathrm{sec})\end{array}$ & WIP \\
\hline Bar Cutting & 10 & 0 \\
\hline Upsetting & 7 & 0 \\
\hline Piercing & 12 & 0 \\
\hline Annealing & 130 & 2000 \\
\hline CNC Machining & 105 & 1200 \\
\hline Drilling & 65 & 950 \\
\hline Threading & 35 & 840 \\
\hline Inspection \& Packing & 45 & 880 \\
\hline
\end{tabular}

Table 3 Detail of Changeover Time of Different Processes

\begin{tabular}{|c|c|c|}
\hline Processes & $\begin{array}{c}\text { AVG. Change Over } \\
\text { Time }(\mathrm{sec})\end{array}$ & No. of Operator \\
\hline Bar Cutting & 15 & 1 \\
\hline Upsetting & 12 & 1 \\
\hline Piercing & 10 & 1 \\
\hline Annealing & 7 & 1 \\
\hline CNC Machining & 25 & 1 \\
\hline Drilling & 20 & 1 \\
\hline Threading & 25 & 2 \\
\hline Inspection \& Packing & 0 & 1 \\
\hline
\end{tabular}




\section{(a) Takt Time Calculation}

Available working day in a week $=6$ days

Demand per day $=\frac{5000}{6}=833$ units

$$
\begin{array}{r}
\text { TAKT Time }=\frac{\text { Net available time per day }}{\text { Customer demand per day }} \\
=\frac{79200}{833}=95 \text { seconds }
\end{array}
$$

It is clear from the above the two processes (Annealing, CNC machining, generally takes higher time than Takt time. So these two processes Annealing and $\mathrm{CNC}$ machining need more improvement.

\section{(b) Analysis of Work in Process}

Current state map shows the work in process (WIP) in different processes. It can be seen that the processes Annealing and CNC machining have the maximum inventory. As shown in current state map reason for high WIP is longer cycle time. So there is need of improvement at these processes.

\section{(c) Number of Work Station Required}

$$
\begin{aligned}
& \text { Line cycle time }(\text { LCT })=\text { sum of all cycle times } \\
& \begin{aligned}
&=10+7+12+130+105+65+35+45=409 \\
& \text { Number of work station required }=\frac{\text { LCT }}{\text { TAKT Time }} \\
&=\frac{409}{95}=4.3
\end{aligned}
\end{aligned}
$$

So there is a requirement of 5 work station.

\section{FUTURE STATE MAP}

The future state map is draw to give propose suggestions and recommendations for improvement in the current position of the company. The future state map below shows all the areas that require improvement and the ways it can be improved. If all the suggestions are implemented gradually in an incremental way then the Production Lead Time for the product will be 3.8 days which is 7.3 days earlier. The processing time is also reduced from 409 seconds to 344 seconds.

As there is no proper organization of what is stored where, there is no proper space for inspection tools and there is problem regarding material handling. In order to minimize these issues, $5 \mathrm{~S}$ 
event needs to be started which is a Japanese concept meaning, a process of creating workplace cleanliness and organization. The 5S stand for Sort (Organization), Set in order (Orderliness),

Shine (Cleanliness), Standardize (Standardized Clean-up), Sustain (Discipline). This needs to be strictly followed so that the following benefits can be achieved.

- $\quad$ Thoroughly eliminate waste due to surplus inventory.

- $\quad$ Reduce space requirements.

- $\quad$ Adopt better storage methods.

Finally Future state map concluded that implementing the above techniques and suggestions would reduce the Production Lead Time to a large extent and smoothen production flow. The hidden waste, inventory would be reduced.

\section{RESULTS \& SUGGESTIONS}

Every industry aims to minimize work in process. Work in process requires storage space, represents bound capital not available for investment and carries an inherent risk of earlier expiration of shelf life of the products. While drawing current state map excessive WIP was found which cause longer Production Lead Time. Use of lean techniques and line balancing WIP reduces a greater extent.

Table 4 Reduction in the work in process

\begin{tabular}{|c|c|c|}
\hline Processes & $\begin{array}{c}\text { WIP in } \\
\text { Current map }\end{array}$ & $\begin{array}{c}\text { WIP in } \\
\text { Future map }\end{array}$ \\
\hline Annealing & 2000 & 610 \\
\hline CNC Machining & 1200 & 600 \\
\hline Drilling \& Threading & 1790 & 580 \\
\hline Inspection \& Packing & 880 & 305 \\
\hline
\end{tabular}

There is also reduction in total processing time which reduces the WIP at work station.

\begin{tabular}{|l|c|c|l|}
\hline \multicolumn{1}{|c|}{ Time } & $\begin{array}{c}\text { Current } \\
\text { state } \\
\text { map }\end{array}$ & $\begin{array}{c}\text { Future } \\
\text { state } \\
\text { map }\end{array}$ & $\%$ reduction \\
\hline $\begin{array}{l}\text { Total } \\
\text { Processing } \\
\text { Time }\end{array}$ & $409 \mathrm{sec}$ & $344 \mathrm{sec}$ & $15.9 \%$ \\
\hline
\end{tabular}

For improvement in these areas there are some suggestions for TEI regarding the shop floor activities.

- A warehouse is required to store the raw material. As discussed earlier in current state map there is no provision for storage of raw material. This results in better storage and handling of raw material. 
- It is suggested that drilling and threading operation can be done on the ground floor near the CNC machining so that the unnecessary movement of man and material is reduced.

- A supermarket is used for better storage and maintaining the Work in Process.

- At inspection and packing workstation there is no proper space for finished product or shipping product. So it is suggested to use $5 \mathrm{~S}$ lean technique for arranging the shop floor space.

- To reduce the Production Lead Time and inventory production line should be balanced. The cycle time should be near to the Takt time most possibly. Instead of linear flow parallel flow should be promoted.

\section{CONCLUSION}

The focus of the research study has to apply value stream mapping in a manufacturing industry for reduction in the WIP and Production Lead Time.

Before drawing the current state map, value must be defined according to the customer level, the delivery team level and the product level. This is done in order to determine which activities add value to the product and which do not. After drawing the current state map different areas of improvement were founded. There is improvement in the WIP and Production Lead Time. Many other suggestions proposed to the industry for improvement.

Finally, the primary focus of this research was how value stream mapping can used as a tool to identify waste in the industry, with a focus on WIP and Production Lead Time. It was shown that value stream mapping is an ideal tool to expose the waste in a value stream and to identify tools for improvement.

\section{REFERENCES}

[1] F. R. Jacobs, R. B. Chase, and N. J. Aquilana, Operations and supply management, 12th ed. New York: McGraw-Hill Irwin, 2009.

[2] J. P. Womack, D. T. Jones, and D. Ross, The machine that changed the world. New York: Harper Collins Publishers, 1991.

[3] D. P. Hobbs, Lean manufacturing implementation: a complete execution manual for any size manufacturer. Boca Raton: J. Ross Publishing, 2004.

[4] A. K. Sahoo, N. K. Singh, R. Shankar, and M. K. Tiwari, "Lean philosophy: implementation in a forging company," Int J Adv Manuf Technol, vol. 36, no. 5-6, pp. 451-462, 2008.

[5] F. Farhana and A. Amir, "Lean Production Practice: the Differences and Similarities in performance between the companies of Bangladesh and other Countries of the World," Asian Journal of Business Management, vol. 1, pp. 32-36, 2009.

[6] M. H. D. Rajenthirakumar, "Process Cycle Efficiency Improvement Through Lean: A Case Study," International Journal of Lean Thinking, 2011.

[7] J. P. Womack and D. T. Jones, Lean thinking: banish waste and create wealth in your corporation. New York: Simon \& Schuster, 1996.

[8] C. Grewal, "An initiative to implement lean manufacturing using value stream mapping in a small company," Int. J. Manufacturing technology and management, pp. 55-61, 2006.

[9] T. Ohno, The Toyota production system: Beyond large-scale production, I ed. Productivity Press, 1988.

[10] M. Rother and J. Shook, Learning to see: Value stream mapping to add value and eliminate muda, 2nd ed. Brookline, MA: The Lean Enterprise Institute Inc, 1999. 
International Journal of Recent advances in Mechanical Engineering (IJMECH) Vol.3, No.4, November 2014

[11] D. W. Halpin and M. Kueckmann, "Lean Construction \& Simulation," in Proceedings of the Winter Simulation Conference, 2001, pp. 131-139.

[12] R. M. Chitturi, D. J. Glew, and A. Paulls, "Value stream mapping in a jobshop," in International Conference on Agile Manufacturing, Durham, UK, 2007, pp. 142-147.

[13] M. Bo and M. Dong, "Research on the Lean Process Reengineering Based on Value Stream Mapping," Management Science and Engineering, pp. 103-106, 2012. 